Review

\title{
Orthodontic Approach to Patients with Autism: A Review
}

\author{
Zeynep Çoban Büyükbayraktar (iD, Cenk Doruk
}

Department of Orthodontics, Cumhuriyet University School of Dentistry, Sivas, Turkey

Cite this article as: Cite this article as: Çoban Büyükbayraktar Z, Doruk C. Orthodontic Approach to Patients with Autism: A review. Turk J Orthod 2019; 32(3): $172-5$

\begin{abstract}
Autism is a complex neurobehavioral disorder that causes problems in thinking, feeling, language, and the ability to communicate with other people. Over the past two decades, there has been a great deal of interest in autism disorder. This problem is recognized worldwide, and various measures are taken both nationally and internationally to improve the lives of affected individuals and families.

The oral health care of such patients can be complicated since they cannot express their problems and can show unpredictable behaviors during treatment. The aim of the literature review was to collect information about the general oral health status of patients with autism, the difficulties that may be encountered during treatment, and the precautions that can be taken and the treatment approaches. This article reviews the dental literature from 1943 to the present.
\end{abstract}

Keywords: Behaviour modification, autism, orthodontic approach

\section{INTRODUCTION}

Autism disorder (AD) was first identified by Leo Kanner, an American child psychologist, in 1943. He examined 11 children whose behaviors were clearly different from other children and suspected that there was an innate trait that impeded children's social relationships (1). AD was classified as infantile autism, childhood autism, and Kanner autism. Autism is a lifelong neurodevelopmental disorder, affecting children while they are young. Children with autism often exhibit multiple and complex deficiencies in their social, emotional, and communicative skills and repetitive behaviors (2).

Genetic and environmental factors are thought to be effective in the development of autism. Factors, such as CNTNAP2 gene, de novo mutations, mitochondrial defects (3), increased level of inflammatory cytokines, maternal bleeding during pregnancy, metabolic syndromes, and advanced maternal age (4), are thought to be effective. Some patients with AD showed abnormal levels of serotonin or other neurotransmitters that can affect brain development. Prenatal factors, such as intrauterine viral infections or metabolic disorders and intrauterine exposures to teratogenic drugs, thalidomide, and valproate (5), may all play important roles in the pathogenesis of AD.

\section{Oral Health and Oral Health Behavior}

Various results have been found in studies on children with autism with regard to caries and periodontal status. In a population-based study, parents reported that their children's teeth were in worse condition than other children (6). On the other hand, some other studies have shown that there was no significant difference between individuals with autism and without autism with regard to the prevalence of cavity $(7,8)$. In some studies, low cavity frequency and severity were determined $(9,10)$. Some drugs used for patients with autism may affect the flow of saliva, and this may lead to an increased risk of cavity (11).

Blomqvist et al. (12) found that the risk of cavity increases in patients with autism due to less frequent brushing and reduction in saliva flow rate. In the same patient group, gingivitis was found to be low despite less teeth 
brushing frequency. Several factors can explain these findings; they had significantly more buccal surfaces with gingival recessions that indicate a persistent, intensive teeth brushing technique (possibly related to pervasive behaviors), and they also reported less frequent snacking, which generates lower levels of dental plaque (12).

In the study conducted by Jaber (13), it has been determined that patients with autism had a high risk of cavity, poor oral hygiene, and unmet treatment. Therefore, it was recommended to focus on protective practices (13). In another study, similar to the control group in individuals with autism, high gingival inflammation, poor oral hygiene, and low $\mathrm{pH}$ value in saliva were determined (14). Since children with autism have poor language coordination, they prefer soft and sugary foods and keep them in the mouth for long periods instead of swallowing. The risk of caries can be high due to the preference of this type of food, keeping foods in the oral cavity for a long time, lack of motor coordination, and high sensitivity to the taste of toothpaste, as well as difficulties in teeth brushing (15).

\section{Oral Habits and Malocclusion}

In addition to self-injurious behaviors, such as hitting with bare hands, banging their heads on walls and furniture, and pricking or pinching (16), oral habits, including bruxism, tongue thrusting, lip biting, and pica (eating objects and substances, such as gravel or pens), have been reported among children with autism (17). In a previous study, oral habits were higher in individuals with autism than in individuals without autism. The most common oral habit was found to be bruxism. Bruxism, tongue biting, object biting, and thumb sucking were significantly higher in children with autism than in the control group (18). These habits may contribute to significant dental problems, such as soft tissue injury, tooth loss, tooth wear, increased overjet, anterior open bite, and posterior crossbite (19). Deformation of the skeletal and dentoalveolar systems may occur due to the frequency and severity of the habit. Individuals with autism did not show a specific malocclusion, but a tendency to deep palate and anterior open bite was observed (20).

\section{Difficulties Experienced During Dental Treatment}

The hypersensitivity and sensory inputs of individuals with autism are difficult to predict and cause difficulties in dentistry because dentistry services are usually performed under bright light and include high sounds, strong flavors, or smells (21). There may be difficulties during treatment sessions due to the lack of communication and bonding abilities in children with autism. Failure of controlling emotions, recurrent body movements, and hyperactivity associated with attention deficit may also cause difficulties during treatment (22). In addition to these difficulties, the insufficient number of trained specialists and the low number of appropriate treatment environments make treatment difficult. In a previous study, it was found that individuals with autism who do not have a medical home and exhibit severe autistic features need a high level of treatment (23). In a study conducted in Riyadh, it was found that individuals serving in autism centers do not have sufficient knowledge and equipment about dental care (24).

\section{Preventive Dental Care}

Early and routine preventive dental care visits are crucial with regard to caries-risk assessment. Nevertheless, many people are unaware of the importance of primary teeth and do not perceive a need for preventive dental care for young children (25). Preventive practices are of particular importance for individuals with autism due to the high risk of cavities and difficult access to treatment services (26). Children with autism who have special health care needs had more dental visits involving restorative/surgical needs but were less likely to have preventive dental care visits than children who did not have special health care needs (27). Concurrently, it was determined that access to preventive practices was restricted due to unemployment and financial reasons (25). Obstacles in front of the preventive practices should be evaluated with regard to our community, and competent authorities should be informed.

\section{Behavioral Management Approaches}

The aim of the behavior management techniques is to reduce anxiety, to make a successful treatment by increasing compliance, and to establish a successful relationship between the specialist and the patient (28).

\section{Communication}

Communication guidance helps to establish trust and builds necessary cooperation. It is a technique that can be applied also to individuals with autism as it is applied to individuals without autism. It includes the following procedures: telling, showing, and doing immediate, frequent positive and negative reinforcements (29). "Tell-show-do" is a basic and effective exposure therapy and a way to introduce dental instruments, equipment, or procedures to a patient (30). The aim of the process is explained by using pictures and objects.

Desired behaviors are rewarded with positive empowerment. In this way, repetition of these behaviors is provided. Positive reinforcement can be done by verbal appreciation of a behavior and thanking. It is also a good way for the parent to be with the patient during the procedure (31).

\section{Visual Pedagogy}

In a study conducted in 1999, it was observed that patients with autism were treated with visual support technique (32). A picture book was used, and each session of the treatment was depicted in the book. Results showed that children were fully cooperative compared with controls. The expert can develop some exercises that can be performed at home by the individual with autism to be familiar with the instruments and the statements used during treatment (33).

\section{Pharmacological Behavior Management Approaches}

The effect of conscious sedation on children with autism may be variable. Conscious sedation can be selected as a treatment plan if the patient needs two surgery appointments or a minimum of dental treatment needs. Patients with autism can also be treated under general anesthesia (31).

\section{Applied Orthodontic Treatments}

In individuals with autism (PubMed, between 1979 and 2017), some treatments have been found, such as the use of removable 
appliances containing nickel titanium (Ni Ti) spring to position the upper incisors behind, anterior crossbite correction, orthognathic surgery, and four premolar extractions.

Ozsoy and Bingöl (34) have successfully performed four premolar extraction treatments for a 17-year-old individual with autism who had Class I malocclusion, increased vertical growth angles, protruded upper and lower incisors, and inconsistent lip closure.

Methods, such as tell-show-do, voice control, positive reinforcement, and behavior modification, were used to increase patient's compliance during treatment. When the patient was afraid, he started to murmur his favorite song. The treatment was completed within 13 months (34). In a previous study, lower bone mineral density was detected in male patients with autism (35). The shortened treatment duration may be related to decreased bone mineral density levels, resulting in faster tooth movement. Gingival inflammation was observed due to poor oral hygiene during treatment (34).

The rates of angle Class II malocclusion characterized by increased overjet among patients with autism can be high (10). In many studies, it has been reported that the frequency of dental trauma is high in these patients due to increased overjet. When the overjet is $>3 \mathrm{~mm}$, the risk of dental trauma is doubled (36). Therefore, treatment of increased overjet is important. Saito et al. used $\mathrm{Ni}$ Ti spring with a removable orthodontic appliance to position the upper incisors behind.

Saito et al. (37) have made some suggestions for the success of such treatments as follows:

1. Appliances should be as small as possible because hyperesthesia can be seen in patients with autism.

2. Appliances should be reinforced with the help of wires.

3. Ni Ti wire must not come into contact with opposite teeth because occlusal forces can break the wire.

As a result of the study, it has been found that removable orthodontic appliances with reinforced resin infrastructure and $\mathrm{Ni}$ Ti wire can be used for such patients (37). In another study, it was observed that a patient with anterior crossbite could tetea-tete position the incisors when he is given a muscle relaxant under general anesthesia. At the second session of general anesthesia, the upper central teeth were placed on the acrylic bite plane. And at the next stage, the lower incisors were placed on the acrylic bite plane under general anesthesia. As a result of 12-month treatment, $3 \mathrm{~mm}$ overbite and $1 \mathrm{~mm}$ overjet were obtained (38).

In the literature, the treatment of a 12-year-old patient with autism is described in a case report. The patient had increased overjet, anterior open bite, vertical growth pattern, and tongue thrusting. Although the ideal treatment method was orthognathic surgery, an alternative method was applied because of the neurological problem of the patient. The treatment of the patient was successfully completed within 3 years by using $\mathrm{Hy}$ rax, high pull headgear, transpalatal arch, and elastics. Tongue thrusting was controlled by using a wrap around the appliance in the patient. The treatment was reported to be successful because treatment was performed with appropriate behavioral guidance techniques (39).

\section{CONCLUSION}

As each patient is an individual, a thorough understanding about each patient is necessary. The dental management of a child with $A D$ requires in-depth understanding of the autistic behavioral profile. A treatment approach based on the correct behavior orientation will provide successful results.

Peer-review: Externally peer-reviewed.

Author Contributions: Concept - Z.Ç.B.; Design - Z.Ç.B.; Supervision - C.D.; Resources - Z.Ç.B; Materials - Z.Ç.B.; Data Collection and/or Processing - Z.Ç.B.; Analysis and/or Interpretation - Z.Ç.B., C.D.; Literature Search - Z.Ç.B.; Writing Manuscript - Z.Ç.B; Critical Review - Z.Ç.B., C.D.; Other - Z.Ç.B.

Conflict of Interest: The authors have no conflict of interest to declare.

Financial Disclosure: The authors declared that this study has received no financial support.

\section{REFERENCES}

1. Kanner L. Autistic disturbances of affective contact. Nervous child 1943; 2(3): 217-250.

2. Association AP, Diagnostic and statistical manual of mental disorders (DSM-5 ${ }^{\oplus}$ )edn. American Psychiatric Pub 2013.

3. Dhillon S, Hellings JA, Butler MG. Genetics and mitochondrial abnormalities in autism spectrum disorders: a review. Curr Genomics 2011; 12: 322-32. [CrossRef]

4. Sandin S, Hultman CM, Kolevzon A, Gross R, MacCabe JH, Reichenberg $A$. Advancing maternal age is associated with increasing risk for autism: a review and meta-analysis. J Am Acad Child Adolesc Psychiatry 2012; 51: 477-86. [CrossRef]

5. Williams G, King J, Cunningham M, Stephan M, Kerr B, Hersh JH. Fetal valproate syndrome and autism: additional evidence of an association. Dev Med Child Neurol 2001; 43: 202-6. [CrossRef]

6. Kopycka-Kedzierawski DT, Auinger P. Dental needs and status of autistic children: results from the National Survey of Children's Health. Pediatric Dentistry 2008; 30: 54-8.

7. Bassoukou IH, Nicolau J, dos Santos MT. Saliva flow rate, buffer capacity, and pH of autistic individuals. Clin Oral Investig 2009; 13: $23-$ 7. [CrossRef]

8. Rai K, Hegde AM, Jose N. Salivary antioxidants and oral health in children with autism. Arch Oral Biol 2012; 57: 1116-20. [CrossRef]

9. Loo CY, Graham RM, Hughes CV. The caries experience and behavior of dental patients with autism spectrum disorder. J Am Dent Assoc 2008; 139: 1518-24. [CrossRef]

10. Orellana LM, Silvestre FJ, Martínez-Sanchis S, Martínez-Mihi V, Bautista D. Oral manifestations in a group of adults with autism spectrum disorder. Med Oral Patol Oral Cir Bucal 2012; 17: 415-9. [CrossRef]

11. Hsia Y, Wong AY, Murphy DG, Simonoff E, Buitelaar JK, Wong IC. Psychopharmacological prescriptions for people with autism spectrum disorder (ASD): a multinational study. Psychopharmacology 2014; 231: 999-1009. [CrossRef] 
12. Blomqvist MS, Bejerot S, Dahllöf G. A cross-sectional study on oral health and dental care in intellectually able adults with autism spectrum disorder. BMC Oral Health 2015; 15: 81. [CrossRef]

13. Jaber MA. Dental caries experience, oral health status and treatment needs of dental patients with autism. J Appl Oral Sci 2011; 19: 212-7. [CrossRef]

14. Diab HM, Motlaq SS, Alsharare A, Alshamery A, Alshammery N, Khawja SG, et al. Comparison of gingival health and salivary parameters among autistic and non-autistic school children in Riyadh. J Clin Diagn Res 2016; 10: 110-3. [CrossRef]

15. Mc Donald R, Avery D. Dentistry for the child and adolescent. St. Louis: Mosby-Year Book. Inc. 1994.p.601-11.

16. Weddell JA, Sanders BJ, Jones JE. Dental problems of children with special health care needs. In: McDonald and Avery's Dentistry for the Child and Adolescent (Tenth Edition). Editon edn: Elsevier 2016: 513-9. [CrossRef]

17. Medina AC, Sogbe R, Rey AMG, Mata M. Factitial oral lesions in an autistic paediatric patient. Int J Paediatr Dent 2003; 13: 130-7. [CrossRef]

18. Al-Sehaibany FS. Occurrence of oral habits among preschool children with Autism Spectrum Disorder. Pak J Med Sci 2017; 33: 115660. [CrossRef]

19. Bell RA. Management of the developing occlusion. McDonald and Avery's Dentistry for the Child and Adolescent. 9th ed. Maryland Heights, Mo: Mosby Elsevier: 2011.p.550-613. [CrossRef]

20. Ozgen H, Hellemann GS, Stellato RK, Lahuis B, Daalen EV, Stall WG, et al. Morphological features in children with Autism spectrum disorders: A matched case-control study. J Autism Dev Disord 2011; 41: 23-31. [CrossRef]

21. Stein LI, Polido JC, Mailloux Z, Coleman GG, Cermak SA. Oral care and sensory sensitivities in children with autism spectrum disorders. Spec Care Dentist 2011; 31: 102-10. [CrossRef]

22. Klein U, Nowak A. Autistic disorder: a review for the pediatric dentist. Pediatric Dentist 1998; 20: 312-7.

23. McKinney CM, Nelson T, Scott JM, Heaton LJ, Vaughn MG, Lewis CW. Predictors of unmet dental need in children with autism spectrum disorder: results from a national sample. Acad Pediatr 2014; 14: 62431. [CrossRef]

24. Murshid EZ. Dental knowledge of educators and healthcare providers working with children with autism spectrum disorders. Saudi Med J 2015; 36: 1477-85. [CrossRef]

25. Wiener RC, Vohra R, Sambamoorthi U, Madhavan SS. Caregiver Burdens and Preventive Dental Care for Children with Autism Spec- trum Disorder, Developmental Disability and/or Mental Health Conditions: National Survey of CSHCN, 2009-2010. Matern Child Health J 2016; 20: 2573-80. [CrossRef]

26. Lewis $C$, Robertson AS, Phelps $S$. Unmet dental care needs among children with special health care needs: implications for the medical home. Pediatrics 2005; 116: 426-31. [CrossRef]

27. lida H, Lewis C, Zhou C, Novak L, Grembowski D. Dental care needs, use and expenditures among US children with and without special health care needs. J Am Dent Assoc 2010; 141: 79-88. [CrossRef]

28. Clinical A.C.-B.M.S. and A.A.o.P. Dentistry. Guideline on Behavior Guidance for the Pediatric Dental Patient. Pediatric Dentistry 2015; 37: 57.

29. Lowe O, Lindemann R. Assessment of the autistic patient's dental needs and ability to undergo dental examination. ASDC J Dent Child 1985; 52: 29-35.

30. Klingberg G. Behavior management-children and adolescents. Disability and Oral Care 2000.

31. Chandrashekhar S, Bommangoudar JS. Management of Autistic Patients in Dental Office: A Clinical Update. Int J Clin Pediatr Dent 2018; 11: 219-27. [CrossRef]

32. Bäckman B, Pilebro C. Visual pedagogy in dentistry for children with autism. ASDC J Dent Child 1999; 66: 325-31.

33. Hernandez P, Ikkanda Z. Applied behavior analysis: behavior management of children with autism spectrum disorders in dental environments. J Am Dent Assoc 2011; 142: 281-7. [CrossRef]

34. Özsoy ÖP, Bingöl Sİ. Extraction Orthodontic Treatment in an Autistic Patient. Turk J Orthod 2017; 30: 28-32. [CrossRef]

35. Neumeyer AM, Gates A, Ferrone C, Lee H, Misra M. Bone density in peripubertal boys with autism spectrum disorders. J Autism Dev Disord 2013; 43: 1623-9. [CrossRef]

36. Nguyen QV, Bezemer PD, Habets L, Andersen BP. A systematic review of the relationship between overjet size and traumatic dental injuries. Eur J Orthod 1999; 21: 503-15. [CrossRef]

37. Saito K, Jang I, Kubota K, Hoshino T, Hotokezaka H, Yoshida N, et al. Removable orthodontic appliance with nickel-titanium spring to reposition the upper incisors in an autistic patient. Spec Care Dentist 2013; 33: 35-9. [CrossRef]

38. Olsen CB. Anterior crossbite correction in uncooperative or disabled children. Case reports. Aust Dent J 1996; 41: 304-9. [CrossRef]

39. Linares TSM, Ruiz DR, Uribe-Querol E. Camouflage orthodontic treatment in an autistic class II patient with anterior open bite: Case report. Revista Mexicana de Ortodoncia 2015; 3: 47-55. [CrossRef] 